GRAŻYNA TEUSZ

ORCID 0000-0003-2745-2480

Uniwersytet im. Adama Mickiewicza

$w$ Poznaniu

\title{
ZNACZENIE „DOŚWIADCZENIA HERMENEUTYCZNEGO” W UJĘCIU H.-G. GADAMERA DLA EDUKACJI*
}

Aвstract. Teusz Grażyna, Znaczenie "doświadczenia hermeneutycznego" w ujęciu H.-G. Gadamera dla edukacji [The Importance of the "Hermeneutical Experience" in H.-G. Gadamer's View for Education]. Studia Edukacyjne nr 53, 2019, Poznań 2019, pp. 275-284. Adam Mickiewicz University Press. ISSN 1233-6688. DOI: 10.14746/se.2019.53.15

The aim of the article is to present the meaning and essence of the "hermeneutical experience" in the H.-G. Gadamer's perspective for the theory and educational practice. The topics address the relationship between pedagogy and philosophy, the presence of philosophical ideas in the reflection on upbringing and the practice of upbringing.

Key words: H.-G. Gadamer, hermeneutics, experience, education

Rozważając pojęcie oraz istotę doświadczenia hermeneutycznego, H.-G. Gadamer wskazuje trzy czynniki:

- rozważaną przez Arystotelesa jedność i ogólność doświadczenia,

- analizowany przez Hegla dialektyczny charakter wszelkiego doświadczenia,

- dokonujący się $\mathrm{w}$ doświadczeniu bolesny i nieprzyjemny proces wglądu i zrozumienia, jako uświadomienie sobie granic i skończoności ludzkiego bytu, powiązany z otwartością na nowe doświadczenie, szczególnie zaś na doświadczenie innego. „Najlepszym świadkiem na potwierdzenie tego trzeciego momentu istoty doświadczenia (...) - pisze Gadamer - byłby $\mathrm{Aj}$ schylos"

* Bezpośrednim impulsem oraz inspiracją do podjęcia tematu stała się lektura książki J. Bürmanna, Gestaltpädagogik und Persönlichkeitsentwicklung. Theoretische Grundlagen und praktische An- 


\section{Jedność i ogólność doświadczenia}

Jak zauważa Gadamer, Arystotelesa interesuje w doświadczeniu kwestia procesualnego tworzenia pojęć, zdobywanie w jego wyniku wiedzy i uzyskanie prawdy ogólnej. Ogólność stanowi warunek sine qua non poznania naukowego, konieczną przesłankę umożliwiającą poznanie na podstawie obserwacji i wnioskowania.

Jaka to ogólność? Dotyczy ona oczywiście nie poddanych odróżnieniu wspólnych elementów wielu pojedynczych obserwacji. Na ich zapamiętaniu opiera się możliwość przewidywania o jakimś stopniu pewności².

Dla Gadamera doświadczenie istnieje tylko w indywidualnej, jednostkowej obserwacji. Człowiek posiadając zdolność do uogólnienia treści pojedynczego doświadczenia, w zasadniczym znaczeniu odnosi je zawsze do drogi własnego życia, do własnego sposobu egzystencji.

Elementem konstytutywnym doświadczenia jest również to, że obowiązuje ono, zachowuje swoją moc, tak długo, dopóki nie zostanie zmienione, czy niekiedy wręcz unieważnione, zanegowane przez rezultaty nowego doświadczenia ${ }^{3}$.

Zawiera się w tym - pisze Gadamer - zasadnicza otwartość doświadczenia na nowe doświadczenie - nie tylko w tym ogólnym sensie, że błędy są korygowane; raczej zgodnie ze swą istotą wymaga ono ciągłego potwierdzania i dlatego z konieczności staje się czymś innym, gdy brak jest tego potwierdzenia (ubi reperitur instantia contradictoria $)^{4}$.

Owa „ogólność doświadczenia” charakteryzuje u Arystotelesa, zdaniem Gadamera, pojęcie indukcji. Z wielu pojedynczych spostrzeżeń, poprzez zapamiętanie i sumowanie wielu szczegółów, wyłania się jedność czegoś ogólnego.

Wydaje się - zauważa Arystoteles - że doświadczenie jest czymś podobnym do wiedzy i umiejętności, ale w rzeczywistości wiedza naukowa i umiejętności praktyczne

sätze eines persönlichen bedeutsamen Lernens, Klinkhardt 1992. Dla autora perspektywą oglądu struktury doświadczenia w ujęciu H.-G. Gadamera oraz jej znaczenia jest specyficzny charakter procesu zachodzącego w Pedagogice Gestalt oraz Terapii Getsalt (s. 203-227). Jak pisze: „Ich möchte darauf abschließend eingehen, um dann einige Gesichtspunkte aufzuzeigen, die auch für gestaltpädagogische (und -therapeutische) Lernprozesse von Bedeutung sind" (s. 219).

${ }^{1}$ H.-G. Gadamer, Prawda i metoda. Zarys hermeneutyki filozoficznej, przekł. B. Baran, Kraków 1993, s. 332.

2 Tamże, s. 327.

${ }^{3}$ J. Bürmann, Gestaltpädagogik und Persönlichkeitsentwicklung, s. 208.

${ }^{4}$ H.-G. Gadamer, Prawda i metoda, s. 328. 
wypływają u ludzi z doświadczenia. (...) Wiedza praktyczna rodzi się wtedy, gdy z wielu postrzeżeń doświadczalnych tworzy się ogólny sąd o podobnych rzeczach. (...) Doświadczenie jest poznaniem poszczególnych przypadków. A wiedza jest poznaniem ogółu 5 .

Doświadczenie, jego ogólność, jego wkład w tworzenie pojęć, stanowi poniekąd dla Arystotelesa, jak to objaśnia Gadamer, jedność naukowego pojęcia lub zasady. Zarazem jednak „doświadczenie istnieje zawsze tylko w jednostkowej obserwacji. Nie jest poznawane jako już z góry ogólne" ${ }^{\prime \prime}$.

Sposób tworzenia pojęć, wyrażony w Arystotelesowskim obrazie „uciekającego wojska"7, poddaje Gadamer zasadniczej reinterpretacji. Jego zdaniem, obraz greckiego filozofa ilustruje narodziny doświadczenia jako momentu, który nie jest zależny od czynników zewnętrznych, ale stanowi proces nieprzewidywalny, spontaniczną, otwartą interakcję. Proces nabywania doświadczenia dokonuje się zatem bez uprzedniego, gotowego scenariusza8. Jest on ponadto zawsze powiązany z ontologicznie pierwotną, jak to ujmuje Gadamer, ogólnością pojęcia oraz konkretnością sytuacji, określonym momentem.

Doświadczenie sensu stricto naukowe zorientowane jest na odkrywanie i formułowanie twierdzeń ogólnych, zasad obiektywizujących określone dane. „Doświadczenie nie jest samą nauką, ale stanowi jej konieczną przesłankę. Musi się już wcześniej potwierdzić, tj. poszczególne obserwacje muszą dawać w prawidłowy sposób to samo" ${ }^{\prime 9}$. Zachodzi jednak, jak zauważa Gadamer, powołując się na Diltheya, konflikt między nauką a filozofią życia ${ }^{10}$. Pewność nauki zasadza się na systematyzowaniu procesów poznawczych, jest rezultatem krytycznej metodologii, wychwytuje to co reprezentatywne $\mathrm{w}$ świecie i przedmiotach, to co jednoznacznie pewne i niepowątpiewalne ${ }^{11}$.

${ }^{5}$ Arystoteles, Metafizyka, przekł. K. Leśniak, Warszawa 1983, ks. I, 981a.

${ }^{6}$ H.-G. Gadamer, Prawda i metoda, s. 328.

7 Gadamer pisze: „Logikę tego procesu przedstawia Arystoteles bardzo pięknym obrazem. Porównuje wielość czynionych obserwacji z uciekającym wojskiem. Również one uchodzą, to znaczy nie zatrzymują się. Gdy jednak pośród tej powszechnej ucieczki jakaś obserwacja potwierdzi się w powtórnym doświadczeniu, wówczas zatrzymuje się. Następuje wtedy niejako pierwszy wyłom w powszechnej ucieczce. Gdy dołączą inne, to w końcu całe uciekające wojsko się zatrzyma i znów będzie słuchać jednego dowódcy. Spójne opanowanie całości uzmysławia tu naturę nauk. Obraz ten ma pokazywać, jak w ogóle może dojść do zaistnienia nauki, tj. prawdy ogólnej, która przecież nie może zależeć od przypadkowych obserwacji, lecz winna obowiązywać jako naprawdę ogólna". H.-G. Gadamer, Prawda i metoda, s. $328-329$.

${ }^{8}$ J. Bürmann, Gestaltpädagogik und Persönlichkeitsentwicklung, s. 210.

${ }^{9}$ H.-G. Gadamer, Prawda i metoda, s. 327.

${ }^{10}$ Tamże, s. 227.

11 Tamże, s. 234. 
Obok tego znajduje się jednak jeszcze to, co Gadamer nazywa, w ślad za fenomenologiczno-egzystencjalnym nurtem myślenia, przede wszystkim zaś za Edmundem Husserlem, „światem życia”.

Przeciwstawiając się pojęciu świata obejmującemu uniwersum tego, co obiektywizowalne przez nauki, Husserl - pisze Gadamer - nazywa to fenomenologiczne pojęcie świata "światem życia”, tj. światem, w którym żyjemy w naturalnym nastawieniu i który nigdy nie staje się dla nas jako taki przedmiotem, lecz stanowi już z góry dane podłoże wszelkiego doświadczenia. (...) Jako horyzontu ów „świat” jest istotowo odniesiony do subiektywności, a odniesienie to oznacza zarazem, że istnieje on „w strumieniu chwil”. Świat życia istnieje w ruchu stałej względności obowiązywania ${ }^{12}$.

Dla Gadamera Husserlowski „świat życia” oddaje prawdę o dziejowości doświadczenia, wyraża wspólnotowość ludzkiego doświadczenia, ale przede wszystkim jego rys osobowy. Istotnym zaś znamieniem tej osobowej optyki jest dążność podmiotu do zrozumienia świata i samozrozumienia. Rzeczywistość bycia wyznacza ruch myśli; oczywistość, konkretność życiowego kontekstu, subiektywne ogarnięcie życiowej sytuacji, egzystencjalnego "tu i teraz" i stapia się następnie, jak to ujmuje Gadamer, z horyzontem treści tradycji historyczno-kulturowej.

W procesie rozumienia następuje rzeczywiście stopienie się horyzontów, które wraz z zaprojektowaniem horyzontu historycznego zarazem go znosi. Kontrolowany proces takiego stapiania się określiliśmy jako zadanie efektywnodziejowej świadomości ${ }^{13}$.

\section{Dialektyczny charakter oraz negatywność doświadczenia}

Dialektyczny charakter struktury doświadczenia, polegający na sui generis odwróceniu świadomości, na zanegowaniu, zakwestionowaniu subiektywnej pewności, eksplanuje Gadamer opierając się na myśli Hegla, w której doświadczenie jest uważane za samorealizację sceptycyzmu ${ }^{14}$.

W istocie (...) doświadczenie jest zawsze doświadczeniem negatywnym. (...) W obliczu doświadczenia, jakie się robi z jakimś innym przedmiotem, zmienia się jedno i drugie, nasza wiedza i jej przedmiot. Wiemy teraz inaczej i lepiej, a to oznacza: sam przedmiot „nie wytrzymuje". Nowy przedmiot zawiera prawdę o starym. (...) Tym samym zaś pojęcie doświadczenie o które tu chodzi, ujawnia pewien jakościowo nowy moment. Nie oznacza tylko doświadczenia w sensie nauk, jakich ono o tym lub owym dostarcza. Oznacza doświadczenie w całości. Jest to owo doświadczenie, które musi być ciągle nabywane i którego nikt nie może uniknąć. Doświadczenie jest tu czymś, co należy do

\footnotetext{
12 Tamże, s. 241.

13 Tamże, s. 290-291.

14 Tamże, s. 330.
} 
dziejowej istoty człowieka. (...) Doświadczenie w tym sensie zakłada (...) z konieczności wiele zawiedzionych oczekiwań jako jedyną drogę nabywania doświadczenia. (...) Każde doświadczenie, które zasługuje na to miano, przekreśla jakieś oczekiwanie. Tak więc jako swój istotowy moment dziejowy byt człowieka zawiera zasadniczą negatywność, która występuje w istotowej relacji doświadczenia i zrozumienia ${ }^{15}$.

Analizowany przez Hegla dialektyczno-negatywny proces doświadczenia - zauważa Gadamer - ukazuje w konsekwencji zmianę wiedzy o świecie, ale i zmianę podmiotu o sobie, zmianę samoświadmości.

Doświadczony jawi się raczej jako radykalnie niedogmatyczny, jako ktoś, kto z racji tak wielu doświadczeń i nauki, jaką z nich wyciągnął, jest właśnie szczególnie predestynowany do tego, by robić nowe doświadczenia i na nich się uczyć. Dialektyka doświadczenia spełnia się nie w zamykającej wiedzy, lecz w owej otwartości na doświadczenie, powodowanej przez samo doświadczenie ${ }^{16}$.

Samoświadomość, samopoznanie określa się poprzez proces interakcji, zachodzący pomiędzy człowiekiem i rzeczywistością, człowiekiem i światem, nade wszystko zaś pomiędzy osobą i osobą. Rezultatem nie jest tylko poszerzona wiedza, ale nade wszystko jakościowo nowy stopień ontologicznej pewności siebie, zaznaczający się zwiększonym poziomem autorefleksji i samozrozumienia.

Zasada doświadczenia zawiera nieskończenie ważne określenie, że aby przyjąć i uznać za prawdziwą jakąś treść, człowiek musi sam przy tym być, a dokładniej że taką treść ma on znajdować jako pozostającą w jedności i zespoloną z jego pewnościq samego siebie $e^{17}$.

Proces doświadczenia skupi zatem w sobie dwa aspekty poznawcze: przedmiotowy i podmiotowy, osobowy.

\section{Wgląd i samozrozumienie jako istotne momenty doświadczenia}

Dla Gadamera właściwe doświadczenie to takie, „w którym człowiek uświadamia sobie swą skończoność"18, swoje granice. Odwołuje się w tym kontekście do Ajschylosa, a raczej do jego formuły uczenia się przez cierpienie. Przez cierpienie, a więc przez rozczarowania, zawiedzione nadzieje,

\footnotetext{
15 Tamże, s. 331-332.

16 Tamże, s. 332.

${ }_{17}$ G.W.F. Hegel, Encyklopedia nauk filozoficznych, cyt.za: H.-G. Gadamer, Prawda i metoda, s. 331 .

${ }^{18}$ H.-G. Gadamer, Prawda i metoda, s. 333.
} 
przez żywione złudzenia i bolesną akceptację rzeczywistości takiej, jaką ona jest, przez uznanie granic „wszelkiego przewidywania i niepewność wszelkich planów"19.

Dokonywana przez Gadamera deskrypcja nowej świadomości doświadczenia hermeneutycznego polega głównie na wydobyciu aspektu zmiany, jaka zachodzi w relacji człowieka do świata, na podkreśleniu otwartości osoby $\mathrm{w}$ tworzeniu i przeżywaniu siebie $\mathrm{w}$ różnorakich płaszczyznach własnej podmiotowości ${ }^{20}$. Gadamer zaznacza przy tym, że jest to zawsze podmiotowość charakteryzująca się własną dziejowością, dziejowością historycznie jednorazową, ale zakotwiczoną $\mathrm{w}$ nurcie historii i tradycji. I tylko w takim odniesieniu staje się ona świadomością efektywnodziejową ${ }^{21}$.

Wydobyte momenty struktury doświadczenia odnosi następnie Gadamer do sensów tkwiących w sposobach doświadczenia ty.

Istnieje - pisze filozof - pewne doświadczenie ty, które poszukuje typowości w zachowaniach bliźnich i na gruncie doświadczenia potrafi te zachowania przewidzieć. Nazywany to doświadczenie znajomością człowieka. Rozumiemy innego tak, jak rozumiemy jakiś typowy proces w polu naszego doświadczenia, tj. możemy się nim posłużyć. Zachowanie innego służy nam za środek do naszych celów jak wszelkie pozostałe środki. Patrząc od strony moralnej, taki stosunek do innego jest czystym egoizmem i przeczy moralnemu przeznaczeniu człowieka ${ }^{22}$.

Istnieje też według Gadamera takie doświadczenie i rozumienie ty, gdy

pomimo wciągnięcia osoby w doświadczenie ty, rozumienie ty jest swego rodzaju samoodniesieniem. Rodzi je dialektyczny pozór, jaki niesie z sobą dialektyka relacji ja - ty. Relacja ja - ty nie jest bezpośrednia, lecz stanowi stosunek refleksywny ${ }^{23}$.

W rezultacie może być tak, że

każdy z partnerów tego stosunku przewyższa innego na drodze refleksywnej. Uważa, że roszczenie innego zna sam z siebie, a nawet lepiej rozumie innego niż on sam siebie rozumie. Ty traci przez to bezpośredniość, z jaką zwraca się ku danej osobie. Jest ono rozumiane, ale (...) jest antycypowane i uchwytywane refleksywnie ze stanowiska innego ${ }^{24}$.

Rozumiejąc innego, wychodząc z założenia, że się go zna, „odbiera mu się zasadność jego roszczeń" 25 . Ta, jak to nazywa Gadamer,

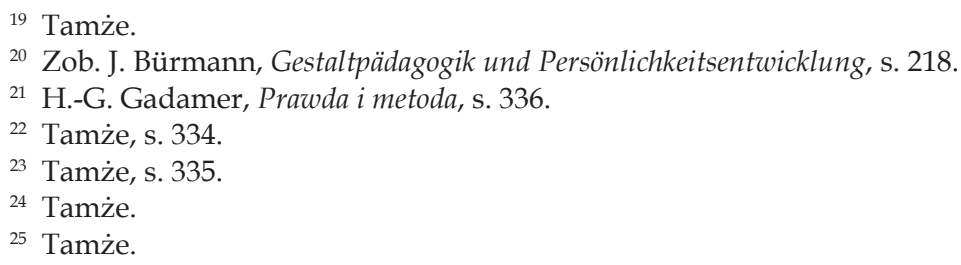

${ }^{20}$ Zob. J. Bürmann, Gestaltpädagogik und Persönlichkeitsentwicklung, s. 218.

${ }^{21}$ H.-G. Gadamer, Prawda i metoda, s. 336.

22 Tamże, s. 334.

23 Tamże, s. 335.

${ }^{24}$ Tamże.

${ }^{25}$ Tamże. 
dialektyka troskliwości daje w ten sposób o sobie znać, gdyż przenika wszelkie międzyludzkie stosunki jako zreflektowana forma dążenia do dominacji. Ambicja, by rozumieć innych już z góry, pełni funkcję trzymania się $\mathrm{w}$ istocie $\mathrm{z}$ dala od roszczenia innego. Jest to dobrze znane ze stosunku pedagogicznego, tej autorytarnej formy troskliwości ${ }^{26}$.

Trzecim aspektem doświadczenia ty jest doświadczenie granicy związane z otwartością na drugiego i na tradycję. Chodzi o doświadczenie drugiego $\mathrm{w}$ pełnej prawdzie jego bytu, z prawem do jej wyrażenia, ponieważ

w relacjach międzyludzkich - zauważa Gadamer - chodzi o to, by ty doświadczać rzeczywiście jako ty, tj. nie przeoczyć jego zagadnięcia i pozwolić mu coś o sobie powiedzieć. Zawiera się w tym otwartość. (...) Bez takiej otwartości na siebie nawzajem nie ma rzetelnego związku między ludźmi ${ }^{27}$.

Ma to daleko idące konsekwencje, ponieważ zmienia nie tylko stosunek do drugiego, ale również odniesienie do samego siebie. „Otwartość na innego obejmuje (...) uznanie, że muszę w sobie przyjąć coś przeciw sobie..." 28.

\section{Znaczenie dla edukacji}

Pytanie o znaczenie, o inspirację koncepcji doświadczenia hermeneutycznego w rozumienia Gadamera dla edukacji wpisuje się w problematykę związków między pedagogiką a filozofią, w zagadnienie obecności filozoficznych rozważań i rozpoznań w teorii i praktyce edukacyjnej ${ }^{29}$.

Dla pedagogów (i pedagogiki) istotne są koneksje z filozofią, bo filozofia daje szansę lepszego zrozumienia świata ludzi i ich myśli, idei, lepszego zrozumienia inspiracji płynących do refleksji o wychowaniu oraz do praktyki wychowania ${ }^{30}$.

Wydaje się, że Gadamerowska teoria doświadczenia hermeneutycznego może stanowić bardzo istotny kontekst dla myślenia o edukacji. Idee autora Prawdy $i$ metody zakreślają wizję rzeczywistości oraz obraz natury ludzkiej, obraz człowieka, który dla refleksji i praktyki edukacyjnej ma przede wszystkim to znaczenie, że łączy, jak to trafnie ujmuje A. Folkierska, „dialektykę

${ }^{26}$ Tamże.

27 Tamże, s. 336.

28 Tamże.

${ }^{29}$ Zob. na ten temat: Filozofia a pedagogika. Studia i szkice, red. P. Dehnel, P. Gutowski, Wrocław 2005.

${ }^{30}$ T. Lewowicki, Filozofia i pedagogika - tradycja i wspótczesność zwiazków inspirujących teorię i praktykę edukacyjna, Colloquia Communia, 2003, 2, s. 18. 
myślenia z dialektycznym procesem życia"31. Dotyczy to przede wszystkim założenia o prymarnej wartości relacji do świata i do drugiego (ty). To wzajemne odniesienie powinno być nacechowane bezpośredniością, otwartością oraz gotowością do przyjęcia rzeczywistości, jak również drugiego w całej ontologicznej prawdzie. Niedopuszczalny jest w tym zakresie jakikolwiek fragmentaryzm czy redukcjonizm. Zachodziłby on na przykład wówczas, kiedy edukacyjna aktywność traciłaby z pola widzenia wagę i znaczenie poszczególnych światów ludzkiego życia, zakotwiczonych w podmiotowych ja osób, które w ramach wyznaczonych przez te światy doświadczają niepowtarzalności i jedyności swojej egzystencji. Chroni to także przed iluzorycznym przeświadczeniem, że można osiągnąć poznanie drugiego wbrew czy też pomimo jego samopoznania, niejako za niego, odbierając mu poprzez tak praktykowana „dialektykę troskliwości (...) zasadność jego roszczeń" ${ }^{32}$. Przywraca natomiast szacunek i zrozumienie dla konstytuującej świat subiektywności, żyjącego tu i teraz człowieka. To ukierunkowanie na świat osoby jest nastawieniem personalistycznym. Jest to, jak się wydaje, przesłanka mająca dla działań edukacyjnych zasadnicze znaczenie.

Chodzi bowiem o to, aby $\mathrm{w}$ podejmowanych aktywnościach $\mathrm{w}$ relacji nauczyciel - uczeń punktem wyjścia uczynić ujmowane doświadczenia tak, jak one się jawią, to znaczy w sposób niezapośredniczony przez konstrukty świadomości, które niejednokrotnie zniekształcają, wykrzywiają, fałszują, upraszczają całą relację. Podmiot - uczeń powinien być zatem zakładany jako ktoś, dla którego jego obszar osobistego doświadczenia ma istotne znaczenie, sens i ważność. Staje się on tym samym partnerem, podmiotem apelującym o rozumiejącą interpretację swojej drogi życia.

W tej perspektywie dopiero ujawnia się źródłowa postać edukacyjnego poznania i działania. Tą źródłową postacią jest życiowa historia oraz kontekst, przeszły i teraźniejszy, drugiego, zarówno nauczyciela jak i ucznia. Poważne potraktowanie owego świata życia indywidualnego ja, uchwycenie go następnie w perspektywie ponadjednostkowego my, w dalszej zaś kolejności poszerzenie o perspektywę dziejowego rozumienia człowieka w ogóle sprawia, że refleksja i działalność edukacyjna zyskuje zupełnie nową dynamikę. $\mathrm{W}$ rezultacie, osiągane $\mathrm{w}$ procesie edukacyjnej aktywności rozumienie, konfrontowane z wyszczególnionymi płaszczyznami, staje się procesem, w którym przeszłość, w myśl koncepcji Gadamera, stapia się z teraźniejszością. Specyficzną bowiem cechą, ontycznym wyróżnikiem ludzkiego ja jest to, że jest ono bezpośrednio i żywo zainteresowane własną biografią w jej konkretnej jednostkowości istnienia i przebiegu, stara się dostrzegać w nim jakiś sens, bądź też niejednokrotnie usilnie go poszukiwać. Partykularność

\footnotetext{
${ }^{31}$ A. Folkierska, Jaka filozofia, jaka pedagogika? [w:] Filozofia a pedagogika, s. 45.

${ }^{32}$ H.-G., Gadamer, Prawda i metoda, s. 335.
} 
uświadomienia sobie postaci i znaczenia własnej drogi życia stanowi zarazem centralny wymiar wglądu, samozrozumienia i samopoznania, uznania i akceptacji, jak mówi Gadamer, własnych granic. Można przyjąć, że każda edukacyjna aktywność, realizująca się poprzez wychowanie i kształcenie, powinna być ukierunkowana na uzyskiwanie wglądu w antropologiczne granice. Odkrycie i uświadomienie sobie tychże granic jest zadaniem stojącym przed uczniem, ale nade wszystko przed nauczycielem, jeżeli chce on rozumieć ucznia i służyć mu pomocą w procesie pełniejszego samopoznania oraz coraz dojrzalszej akceptacji własnego ja i własnej sytuacji życiowej.

Aby lepiej wyrazić na czym polega rozumienie tradycji, przeszłości oraz rozumienie drugiego Gadamer formułuje postulat „wstawienia się w jakąś sytuację". Dla sfery edukacyjnej może on stanowić bardzo instruktywne wskazanie.

Gdy wstawiamy się np. w sytuację innego człowieka, to będziemy go rozumieć, tzn. uświadamiać sobie jego inność, a nawet nieredukowalną indywidualność właśnie przez to, że wstawiamy się w jego sytuację. Takie wstawienie się nie polega ani na wczuciu się jednej indywidualności w inną, ani na przyłożeniu do innego własnej miary, lecz oznacza zawsze wzniesienie się do wyższej ogólności, która przezwycięża nie tylko własną szczególność, ale też szczególność innego ${ }^{33}$.

Droga Gadamerowskiej myśli to droga ujmowania ludzkiego doświadczenia siebie, drugiego oraz rzeczywistości w ich źródłowej postaci tak, jak one się prezentują, niezapośredniczone przez apriorycznie przyjęte, gotowe formuły i konstrukty myślowe. Filozof próbuje wypracować sposoby ujmowania prawdziwej postaci życia, jego uwarunkowań i granic. Formułowane idee: otwartości wszelkiego doświadczenia, jego negatywności, to znaczy możliwości zaprzeczenia dotychczasowej wiedzy i zyskiwania w wyniku doświadczenia nowego jej poziomu, nade wszystko zaś zyskiwania nowego jakościowo momentu pewności siebie oraz konieczności doświadczania drugiego w całej prawdzie jego bytu i egzystencjalnych ram, w jego niepowtarzalnej, jednostkowej podmiotowości, stanowić mogą dla procesów edukacyjnych istotny kontekst, ważną perspektywę i punkt odniesienia.

\section{BIBLIOGRAFIA}

Arystoteles, Metafizyka, przekł. K. Leśniak, Państwowe Wydawnictwo Naukowe, Warszawa 1983.

Bürmann J., Gestaltpädagogik und Persönlichkeitsentwicklung. Theoretische Grundlagen und praktische Ansätze eines persönlichen bedeutsamen Lernens, Bad Heilbrunn/OBB, Klinhardt 1992.

\footnotetext{
33 Tamże, s. 289.
} 
Dehnel P., Gutowski P. (red.), Filozofia a pedagogika. Studia i szkice, Wydawnictwo Naukowe Dolnośląskiej Szkoły Wyższej TWP, Wrocław 2005.

Folkierska A., Jaka filozofia, jaka pedagogika? [w:] Filozofia a pedagogika. Studia i szkice, red. P. Dehnel, P. Gutowski, Wydawnictwo Naukowe Dolnośląskiej Szkoły Wyższej TWP, Wrocław 2005.

Gadamer H.-G., Prawda i metoda. Zarys hermeneutyki filozoficznej, przekł. B. Baran, Wydawnictwo Inter Esse, Kraków 1993.

Lewowicki T., Filozofia i pedagogika - tradycja i wspótczesność związów inspirujących teorię i praktyke edukacyjna, Colloquia Communia, 2003, 2. 